\title{
CAPITAL ACCUMULATION BETWEEN PETRONAS, GOVERNMENT AGENCIES AND BUMIPUTERA ENTREPRENEURS
}

\author{
Saiful Khairi Kamarudin* \\ Puteh Noraihan A Rahman** \\ Taylor's University (Lakeside Campus)
}

\begin{abstract}
Abstrak
The foundation of Petroliam Nasional Berhad (PETRONAS) was one way of increasing the bumiputera's equity. This paved the way to improve the disparity in the Malay social economic conditions with other Malaysian races and subsequently enhanced Malay economic wealth. This article will explore how PETRONAS were able to consolidate the interests of bumiputera socio-economic needs which led to the creation of Malay middle class. The focus of the paper would be on the role of PETRONAS in expanding and sharing its business operations and profitability with government agencies and Malay entrepreneurs. The business expansion would be through the rationalization process to other bumiputera companies or the profit sharing measure through inter-capital relationship or inter-skill benefit.
\end{abstract}

Keywords: Malay Middle Class, Mining Equity, Bumiputera Equity, New

Economic Policy, Petroleum Industry

\section{Introduction}

This paper examines the contribution of PETRONAS in consolidating the interests of Bumiputera socio-economic needs that led to the creation of a Malay middle class. It covers the role of PETRONAS in expanding and sharing its business operations and profitability with government agencies and Malay entrepreneurs. The business expansion would be through the rationalisation process to other Bumiputera companies, or the profit sharing measure would be through inter-capital relationship or inter-skill benefit. This stage of profit sharing was realised after PETRONAS had stabilised its business operation and gained a considerable return on investment after initially spending for capital and operating expenses.

In this establishment period, the periodic years start from 1980 to 1990 . The starting year of 1980 is defined when PETRONAS for the first time had proper cash flow and capital equity higher than a liability. The ending year of 1990 is defined when PETRONAS has ended officially its exclusive rights to implement the New Economic Policy (NEP) in which the government has replaced the NEP to New Development Policy (NDP). The early years to the middle of the 1980s was an initial heydey for PETRONAS, but then its income deteriorated in the late 1980s. By 1980, oil and gas already represented $24 \%$ of Malaysian exports, and the government decided to impose a tax on these exports at a $25 \%$ rate. In 1980, petroleum products accounted for $88 \%$ of the country's commercial consumption of energy, the rest being provided by hydroelectric plants in Sarawak, too far away from the main population centres to become a major alternative. Five years later, gas accounted for $17 \%$, hydroelectricity for $19 \%$, coal for $2 \%$, and petroleum products for $62 \%$ of such consumption, and about 
half of each year's gas output was being consumed in Malaysia. ${ }^{1}$

Since 1980 until 1990, PETRONAS had invested about RM9 billion in upstream and downstream sectors. Instead of investing money into foreign companies having expertise in the upstream sector, part of the investment was also distributed to Bumiputera companies by giving shares, employment, contracts and licences. During the privatisation period in the middle of 1984, the government offered its assets under state-owned enterprises to be sold to PETRONAS and Malay businessmen or corporate figures. These moves enhanced Malay equity in the petroleum industry and indirectly accumulated capital investment through PETRONAS into the hands of Bumiputera companies and government agencies by stimulating ownership in the petroleum business. To know how Bumiputera equity slowly began to control substantial ownership in the petroleum industry, it is also important to examine the method of the Malay ruling party's investment arms, Fleet Holding and Hatibudi Holding that took advantage of using government's trusteeships like PETRONAS in the name of NEP.

\section{Methods of Capital Accumulation Through PETRONAS}

\section{Four Methods of Capital Transfers to Bumiputera}

Despite production sharing contracts (PSC) helping to transfer profit and creating more capital for PETRONAS, there were other means of accumulating capital to Bumiputera through petroleum business activities. This means creating external revenue to Bumiputera whose role acted as corporate director, government official, government agent, entrepreneur and contractor, and they have certain methods to bring income from the petroleum business especially through PETRONAS-National Oil Corporation (NOC) - or by other means of capital sharing through FOC.

There are four methods of capital accumulation that Bumiputera used to practice in increasing equity in the petroleum industry. The methods are ownership, trusteeship, partnership and privilege. Ownership is the method where PETRONAS and government agencies use their authority to protect the rights of federal ownership and state ownership. Trusteeship is the method where directors and trustees in the government-linked companies (GLCs) secure and ensure the increase of share capital among shareholders especially to facilitate majority ownership by Bumiputera.

The partnership is the method where PETRONAS' subsidiaries, GLCs and Bumiputera companies jointly operate and develop petroleum business projects with FOC. Privilege is the method where PETRONAS, GLCs and Bumiputera companies depended on New Economic Policy (NEP) to impose preferential policy in acquiring share capital and contracts from NOC and FOC.

\section{Ownership}

Ownership method was the most viable and fundamental practice in allowing PETRONAS and government agencies to use prerogative clause in petroleum legislation and industrial sanction to overrule the business decision of foreign and nonBumiputera companies in compromising investment agreement in favour of Bumiputera interests. The most viable legislative policy was the Petroleum Development Act (PDA) and Industrial Coordination Act (ICA). The objectives and elements of the PDA helps to protect the ownership of petroleum industry for the interest of the national agenda in preventing international oil companies from 
dominating Malaysian petroleum activities.

By means of ownership, PETRONAS enjoyed the substantial profit from production sharing contracts. Besides that, PETRONAS can dictate FOC to share their equity when the company decided to invest in petroleum activities in the new oil or gas fields. ${ }^{2}$ For instance, the first PETRONAS's involvement in imposing its ownership right was in 1976 when Shell BV, the Royal Dutch Shell subsidiary accepted the production sharing contract (PSC) offered by PETRONAS for an LNG project in Sarawak but baulked at sharing equity, transportation management and refining. ${ }^{3}$ Under this agreement, PETRONAS took $60 \%$ of the equity in the new company Malaysia LNG. The Sarawak state government took 5\%, and the other 35\% was divided equally between Shell BV and the Mitsubishi Corporation. ${ }^{4}$

In 1975, other than the PDA, the Industrial Coordination Act (ICA) was introduced which allowed the government to increase authority over manufacturing enterprises and which provided the bureaucracy with avenues to counter those who side-stepped the essence of the NEP. The Act was roundly condemned by the Chinese who protested the ICA's mandatory ruling that foreign and Chinese companies should ensure at least $30 \%$ Bumiputera participation in all their ventures. ${ }^{5}$ The ICA was subsequently amended, first in 1977, and again in 1979, with a few concessions by the government each time. ${ }^{6}$ The essential premise of the ICA, however, remains intact; except in the case of very small firms, licences would be required from the Ministry of Trade and Industry, and these could be revoked if requirements for Bumiputera ownership and employment were not met. $^{7}$

The MCA aggressively responded to the introduction of ICA by forming Multi-Purpose Holdings Berhad (MPHB), then commonly acknowledged as the party's investment arm, to counter what the party considered a threat to the development of Chinese business interests. ${ }^{8}$ Another major contributory factor to the formation of MPHB was the establishment of government-owned agencies such as PerbadananNasional (PERNAS), the Urban Development Authority (UDA), and the various State Economic Development Corporations (SEDCs), formed in the wake of the New Economic Policy (NEP), and which soon rapidly increased their hold over key sectors of the economy. ${ }^{9}$

\section{Trusteeship}

Trusteeship method was the collective measure of protecting Bumiputera interests in the government's public enterprises and government agencies especially by upholding corporate directorship and equity ownership. The collective protection of equity ownership was working behind the flagship of a political party, such as UMNO, to invoke the legitimacy of the party's business ventures. ${ }^{10}$ In trusteeships such as PETRONAS and its subsidiaries, the question always arises of how the Bumiputera trustees transferred the share capital and investment of petroleum resources to increase the equity of GLCs and Bumiputera privately owned companies? The Malay elites politicians and entrepreneurs - can acquire more equity if the politicians from UMNO and government officials appoint the trustee directors in the government trusteeship to interlock acquisition of share capital between party-linked companies and governmentowned companies.

According to Gomez, trusteeship is the dominant vehicle used to pursue the interests of political and economic elites. This concept refers to the putting of faith in the hands of an individual or organisation to advance a certain policy or duty. ${ }^{11}$ In the Malaysian context, trusteeship is tied closely with the concept of loyalty which is how 
the collective measure works. Often too, appointments as trustees have been a form of patronage wielded by the party's elites as a reward for loyalty. ${ }^{12}$ Trustees involved patronage of the government to ensure business success and protection from competition by maintaining Bumiputera privileges to acquire concessions, licences, monopoly rights, government subsidies and more.

\section{Partnership}

Partnership method is a power-sharing scheme between companies to complete the missing structures and functions in both organisations to pursue an objective of developing big scale projects. The companies forced to seek advantage on the other side of company's unique capability because of its capital funding, business network, organisational influence or reputable talent. In the early 1980s, PETRONAS developed a business partnership with FOC because of lack in internal competencies on technical know-how. ${ }^{13}$

The first well-known PETRONAS business cooperation in 1982 was with Elf Aquitaine of France through the establishment of PETRONAS Carigali. However, this partnership was a joint venture approach whereby PETRONAS Carigali had to provide a capital investment of exploration activities whereas Elf Aquitaine provided talents to execute exploration implementation and also provided training to PETRONAS Carigali employees. The expected profit generated from exploration production had benefited PETRONAS to increase equity as the shareholder to PETRONAS Carigali. ${ }^{14}$

\section{Privilege}

Privilege method is the exclusive right given to Bumiputera and government public enterprises due to the affirmative action policy through the implementation of NEP. The objective of NEP has made a preference to Bumiputera to acquire awards and contracts offered by PETRONAS has led to feelings of exclusiveness because of their racial status as Bumiputera. ${ }^{15}$ Privilege would apply effectively for contracts related to offshore business activities in which segments in petroleum businesses are cascaded into many fields of contract opportunities whether it is petroleum-related product or support services. ${ }^{16}$ This relation can be seen mostly in the retail business whereby Bumiputera had been given licences to open petrol stations and to serve as agents for PETRONAS products. ${ }^{17}$ Because of its direct connection to the Prime Minister, PETRONAS can establish a difficult business deal overseas with easy acceptance from a foreign government given PETRONAS' influence in the government machinery for easy access to bigger resources. ${ }^{18}$

\section{Privatisation in the Petroleum Industry}

\section{Government's Privatisation Projects}

In response to the need to achieve equity in wealth distribution among the main ethnic communities in Malaysia, the government promoted the rise of ethnic Malay-owned business groups. The NEP entailed the partial abandonment of laissezfaire economic management in favour of greater state intervention through public enterprises. ${ }^{19}$ This intervention involved ethnic affirmative action, including the 
accelerated expansion of the Malay middle class and capital accumulation on behalf of the Malays. This capital accumulation called as the transfer of assets ownership to individual Malay through government's privatisation project. From the mid-1980s, the government began to selectively promote the interests of individuals, usually wellconnected Malay businessmen, as a means of creating a pool of new private capitalists. Politicians in power would selectively distribute state-created concessions, or rents, in the form of licences, contracts, and privatised projects. ${ }^{20}$ Funds to acquire these rents were secured through favourable loans from banks owned or controlled by the state.

It is ironical that Mahathir Mohamad before he became Prime Minister, expressed reservations regarding the privatisation of certain sectors. Although he did not oppose the general concept of privatisation, he was of the opinion that 'certain types of industries should be state managed'. ${ }^{21}$ Now these industries for example communications not mass media, but telephone, etc. should not be allowed to be managed by private enterprise. Railways, airlines these are essential for the country, we cannot think of them entirely regarding profits. ${ }^{22}$ However, in reality, under Mahathir's privatisation policy, the national airline, Malaysia Airline System, railways and Telekom Malaysia were all privatised.

Two years after Mahathir's first announcement in 1983, the Economic Planning Unit (EPU) of the Prime Minister's Department issued its Guidelines on Privatisation, which remained the main official document on privatisation until early $1991 .^{23}$ According to Jomo, privatisation has been defined regarding the transfer of enterprise ownership from the public to the private sector. More generally, privatisation - or denationalisation - refers to changing the status of business, service or industry from state, government or public to private ownership or control. ${ }^{24}$ The term sometimes also refers to the use of private contractors to undertake services previously rendered by the public sector. Privatisation can be strictly defined to include only cases of the sale of $100 \%$ or at least a majority share of a public enterprise or assets, to private shareholders. ${ }^{25}$ Full or complete privatisation would, therefore, mean the complete transfer of ownership and control of a government enterprise or asset to the private sector.

The objective of privatisation in Malaysia is to increase private sector involvement in the economic development of the country. By reducing public sector involvement in areas that were traditionally the mainstay of government, such as the highway construction industry, the private sector is encouraged to fill in the vacuum left by the government; selling the equity of public sector agencies to the private sector enables the government to achieve the objective of reducing its economic activities and increasing private sector ownership of the economic resources in the country. ${ }^{26}$

By enhancing the growth prospects of the private sector, particularly the corporate sector, privatisation will provide opportunities for achieving further progress towards fulfilment of the National Development Policy objectives especially with respect to restructuring the ownership pattern in the economy. The privatisation programme will help to enhance Bumiputera shares in the economy by setting aside $30 \%$ of the generated wealth through privatisation to the Bumiputera whose economic standing has improved since the early days of the NEP. ${ }^{27}$

\section{The Creation of Malay Capitalists}

Transfer of ownership to Bumiputera depends on the Industrial Coordination Act (ICA) of 1975 which required that business licences to manufacturers would be issued on condition that there was 30\% Bumiputera equity, $30 \%$ Bumiputera membership on the board of directors and $30 \%$ Bumiputera workforce. ${ }^{28}$ While the 
objectives of privatisation were to improve efficiency and productivity, many inherent contradictions may affect the implementation of the privatisation plan. The need to increase Bumiputera participation and simultaneously generate $30 \%$ share of the corporate equity for them, on one hand, will have to be balanced the need to accelerate investment by all groups whether they are Bumiputera, non-Bumiputera or foreign companies. $^{29}$ This policy limited the ability of privatised entities in the petroleum business segment, such as exploration and trading, to improve production and profitability as they were constrained by the requirements set by PETRONAS vis a vis government concerning regulation of the PDA 1974 in the privatised setting.

In 1981 when Mahathir was appointed Prime Minister, the implementation of the NEP had reached ten years. The government had managed to increase a number of corporate holdings held in the name of Bumiputras from $2.4 \%$ in 1970 to $12.5 \%$ in $1980 .{ }^{30}$ Although Malay equity ownership had improved, Mahathir saw little progress had been made in developing Malay businessmen in control of large corporations. In fact, among the top 100 Malaysian corporations during the mid-1970s, not a single firm was then owned by either the Malaysian government or Bumiputera individuals. ${ }^{31}$ It was precisely this situation that Mahathir sought to rectify. From the outset of his premiership, Mahathir voiced his intention to create an ensemble of dynamic, entrepreneurial Malay capitalists.

The implementation of the privatisation programme during the privatisation plan period the government primarily depended on the strength of individual participation. For instance, shortly before the general elections in October 1990, it was suddenly announced that Food Industries of Malaysia Bhd (FIMA) and Peremba Bhd were being privatised through management buy-outs. The former went to Mohd. Razali Mohd. Rahman and Hassan Abas, both close associates of then Finance Minister Daim, while the latter went to Tan Sri Basir Ismail, reputedly very close to Mahathir, and previously appointed to various powerful and prestigious positions including Chairman of PETRONAS and Bank Bumiputera. ${ }^{32}$ Another important appointment for Basir was to the powerful Capital Issues Committee (CIC), ${ }^{33}$ which approves share issues and company transactions; his appointment to the regulatory body was made despite Basir's extensive corporate holdings. ${ }^{34}$

Regarding the beneficiaries of the privatisation policy, a major issue was whether sufficient Malay or Bumiputera capitalists, with the capacity to operate the projects and enterprises, were available at the time privatisation, although the government had indicated that there was an increasing number of Bumiputera with such capacity. If the government was wrong, then the main beneficiaries of the privatisation policy were the non-Malays especially large Chinese-owned enterprises who were awarded privatisation projects and politically connected Malay companies or actually, UMNO's trustee businessman and companies. ${ }^{35}$ Those who benefited from the privatisation policy included: Halim Saad of Renong, Tajudin Ramli of Malaysian Airline System, Wan Azmi Wan Hamzah, Samsudin Abu Hassan, as well as Mahathir's three sons - Mukhriz Mahathir, Mokhzani Mahathir and Mirzan Mahathir. ${ }^{36}$ They are often regarded as "crony capitalists" groomed by Mahathir. Through their shareholding directorships and nominees in UMNO's investment arms or government public enterprises, Malay politicians and the ruling elites had used them to be proxies in PETRONAS's subsidiaries in transferring share capital ownership and contract awards to Bumiputera interests that were mostly held in subsidiaries of UMNO's investment arms and government public enterprises. ${ }^{37}$ 


\section{Form of Privatisation in the Petroleum Industry}

None of the academic literature discusses the concept of privatisation in the Malaysian petroleum industry. The government's privatisation project in the 1980s was not strongly connoted to the concept of capital transfer from public-owned enterprise to private-owned ownership in the petroleum sector. The establishment of PETRONAS in 1974 was based on the Petroleum Development Act 1974 with the underlying the foundation that PETRONAS has full monopoly powers and privileges in exploiting and developing onshore and offshore petroleum resources. Since then the government has never been developing any plan to transfer this 'privilege' to private enterprise.

Nonetheless, the government created funding to the large number and size of privatised projects for PETRONAS subsidiaries. ${ }^{38}$ This funding was contributed by the Employees Provident Fund (EPF), Lembaga Tabung Haji (LTH) and Lembaga Tabung Angkatan Tentera (LTAT) which generated a massive mobilisation of private sector financial resources under financial institutions for equity financing as well as loans by the banking sector. ${ }^{39}$ In this way, privatised entities were able to resource funds through mobilisation of funds from the local debt and equity markets as well as through the use of innovative methods in obtaining funds. In this regard, PETRONAS Dagangan Berhad and PETRONAS Gas Berhad secured funds through Islamic Debt Securities. ${ }^{40}$ The government also provided soft loans amounting to RM4.8 billion during the privatisation plan period for projects with a high social component. ${ }^{41}$

The main aim of privatisation was to reduce the financial and administrative burden of government. However, the government did not see petroleum sector carried the financial burden of the expense for PETRONAS's administrative and investment purpose. PETRONAS initiated substantial profit of $12.3 \%$ over operating expenses in 1976 just after three years of its establishment. ${ }^{42}$ In 1989, when the government set up its privatisation plan, PETRONAS earned a profit after tax of RM2.4 billion and even more PETRONAS was enabled to acquire Bank Bumiputera Malaysia Berhad's share capital with an investment of RM1.5 billion. ${ }^{43}$ Further to this profitability, PETRONAS had paid a royalty to state governments amounting to RM143 million. ${ }^{44}$ Impressive profitability of PETRONAS and ability to invest capital in government-related companies had shown that PETRONAS was a self-sufficient organisation without receiving any financial aid from the government since its initial profit in 1976. As illustrated in Figure 1, PETRONAS only transferred its ownership over petroleum resources for the government's privatisation plan regarding capital investment in the form of awarding contract to the privatised government's public enterprise.

Figure 1: Privatisation Model on PETRONAS's Ownership Transfer

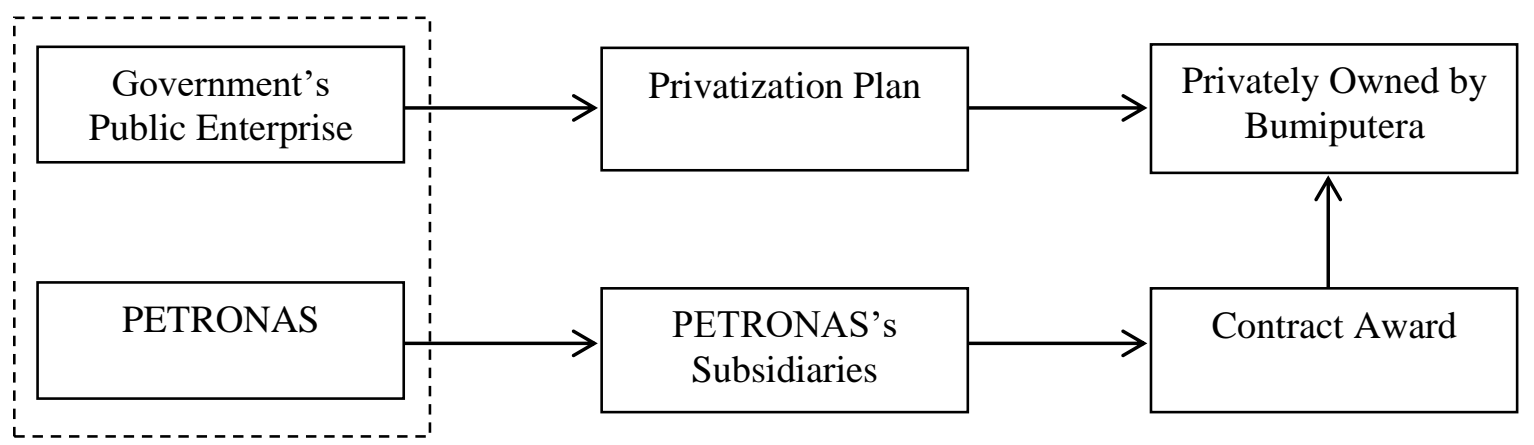


Source: An illustration created by Author.

The petroleum sector in Malaysia is a heavily regulated economy. ${ }^{45}$ This has been concerned with controlling market access in the case of the industrial sector, and with shaping asset-holding behaviour in the case of the capital market. The approach to regulation in Malaysia is to encourage those forms of private investment which contribute to the development of the country, consistent with the NEP objectives.

According to Jomo, this approach has resulted in a heavy emphasis on the form of corporate ownership, rather than on corporate performance, but while there is concern that the over-regulation of the economy - in pursuit of NEP objectives - has constrained growth and accentuated private sector risk-aversion, the experience of recent decades suggests that regulation has been managed relatively judiciously. ${ }^{46}$ This is particularly so in the petroleum sector through the Petroleum Development Act 1974, and in the financial sector through the Securities Industry Act 1983, where the KLSE in particular and the capital market, in general, are regarded as accessible and well-managed markets.

The privatisation plan also emphasised heavy industry; PETRONAS contributed to an upsurge in the number of petroleum-related industries particularly in the petrochemical sector. Among government-owned enterprises were the Heavy Industries Corporation of Malaysia (HICOM) and its subsidiaries which undertook large projects in the petrochemical industry.

Mahathir Mohamad saw PETRONAS working out the PSCs. He needed PETRONAS to play an active role to support the industrial development of the country. Mahathir assumed his preferential figurehead around his political influence to control PETRONAS. He brought in and appointed his close associate Tan Sri Basir Ismail as chairman of PETRONAS by replacing Tan Sri Raja Tun Mohar in 1988. ${ }^{47}$ The placement of Basir in PETRONAS had strengthened Mahathir's brainchild company, HICOM to explore and develop the petrochemical industry in connection withPETRONAS's transformation programme for the strategic moves towards becoming a global business giant in petrochemical products. ${ }^{48}$ Nonetheless, HICOM was apart from upstream business even though connoted to heavy industry development. The upstream business of PETRONAS'Carigali were still within the PETRONAS original core businesses and faithful to the fundamental business of finding and developing the nation's oil and gas resources.

\section{Trusteeship in PETRONAS's Business Interests}

\section{Malays Strategy to Increase Mining Equity}

At the upper level of public trust, PETRONAS is a trusteeship to the government because PETRONAS is a sovereign organisation that must implement and enforce the PDA on behalf of the government. Indirectly, PETRONAS is a trusted agency as a special purpose public enterprise, acquiring equity in the petroleum industry in the name of and on behalf of Bumiputera interest. ${ }^{49}$ Therefore, the form of trusteeship in PETRONAS is mainly represented by government machinery that are in power dominated by the winning political party through the General Election. The UMNO Party that causes for Malays interest has been dominating government machinery since independence. PETRONAS under the direct report of the Prime Minister depends on the accountability held by individual Malays connected to the UMNO. ${ }^{50}$ They are appointed by the Prime Minister as directors to represent 
PETRONAS for upholding the implementation of the PDA and NEP - as the cornerstone of UMNO's cause - with success in the petroleum industry.

The earliest strategy adopted by Malays to acquire equity in the petroleum industry through government's agency vehicles was by initially imposing the government-owned company to increase share capital in the mining industry for the sake of dominating petroleum business and forcing government-owned company as trusteeship to acquire market share in the mining industry. ${ }^{51}$ The involvement of PERNAS, a government-owned corporation, for strategic investment in the mining industry in the early 1970s was to control market share in the tin mining industry by acquiring the two largest tin mining groups, London Tin Ltd and Charter Consolidated Ltd, at that time British-owned concerns. ${ }^{52}$ In 1975, a year after PETRONAS was established, PERNAS through market share purchase had gained a $20 \%$ stake in London Tin. ${ }^{53}$

By 1981, the government stake in the tin business had a major control in the mining industry market share through the acquisition of Charted Consolidated, the second largest tin group in Malaysia after London Tin. The merger changed its name to Malaysian Mining Corporation (MMC) and asserted that the Malays had succeeded in achieving significant control of the mining industry thus advancing the Malay business portfolio in mining related business to the extent of the oil and gas business. This has marked a turning point in Malaysian history that the Malays had replaced Chinese's and foreign ownerships of $89 \%$ in the mining industry and at the same time had controlled mining technology-related network for applying petroleum exploration activities to PETRONAS.

On the one hand, the purchase of equity of a foreign mining company by the government agency in realising the establishment of MMC, a government-owned mining company, had completed the interlocking process of the Malay ruling elites from UMNO to acquire a business in the mining industry ${ }^{54}$ On the other hand, the other UMNO proxy company, UEM, a subsidiary of Hatibudi Holding, an UMNO investment company became the symbiotic trust of the government engineering arm through Malay nominees for the sake of gaining government projects. Furthermore, UEM which had a share stake in MMC's subsidiary, Aokam Tin, completed the interlocking system of the Malay business line. ${ }^{55}$

Prior to Hatibudi owned UEM, the company was a foreign-owned company set up in Singapore under United Engineers Limited (UEL). Later, the Federated Engineering Co. Limited of Kuala Lumpur was added to the company. However, in 1966, the company was regrouped on a territorial basis, and United Engineers (M) SendirianBerhad was incorporated in March 1966. ${ }^{56}$ It was initially engaged in the manufacture and supply of machinery to rubber and tin industries as later in the mid1980s this engagement had given advantage to UEM to prolong its ownership in the mining industry by acquiring Aokam Tin from government-owned company, MMC at the time when the Malaysian petroleum industry was protected and prospered under PETRONAS.

\section{Interlocking Share Capital Ownership Through UMNO's Investment Arms}

At the lower level of public trust, PETRONAS appointed directors by the consent of the Prime Minister. They are also in connection of PETRONAS to represent trustee and nominees who have a stake in PETRONAS's subsidiary companies. ${ }^{57}$ The trustees and nominees are politically connected with Malay elites in UMNO and have preference when acquiring licences and awards offered by PETRONAS. ${ }^{58}$ 
How did the trusteeships like PETRONAS transfer the distribution of state's petroleum resources to the hands of individual Bumiputera? Bumiputera would acquire equity to expand capital ownership if UMNO's party leaders appointed trustee directors in the government trusteeship to interlock share acquisition and ownership between party-linked companies and government-owned companies. This method has been used since UMNO established its 'business corporation' called Fleet Holdings in 1972.

Fleet Holdings was the first UMNO investment arm made up by Tengku Razaleigh; a trustee-director considered the sole buyer of the government's trusteeship project. The primary purpose of establishing Fleet Holdings was to buy a major share in New Strait Times (NSTP). ${ }^{59}$ At that time NSTP was controlled by Singapore and the British. Nevertheless, there were oppurtunities to use Fleet Holdings to acquire equity through the directorship of Tengku Razaleigh in Fleet Holdings and chairmanship in PETRONAS who was the proxy of individual figureheads had relation with UMNOlinked companies and government-owned companies. ${ }^{60}$ The chairman of PETRONAS would directly to transfer of acquiring the allocation of huge assets from PETRONAS. ${ }^{61}$

According to Gomez, a holding company using a pyramiding device gives rise to interlocking share capital ownership as shown in Figure 2. Also, interlocking share capital ownership is to ensure the subsidiaries of the holding company are involved in several key sectors of preferred industries. In effect, this mechanism was meant for getting more dividends and greater share appreciation. ${ }^{62}$ To complete the interlocking, the subsidiary of the company that owned the holding company may acquire a stake in the holding or parent company. This method encourages a monopoly and protection of a certain business sector which creates a network of interdependence between companies. ${ }^{63}$

Figure 2: Model of Interlocking Share Capital Ownership

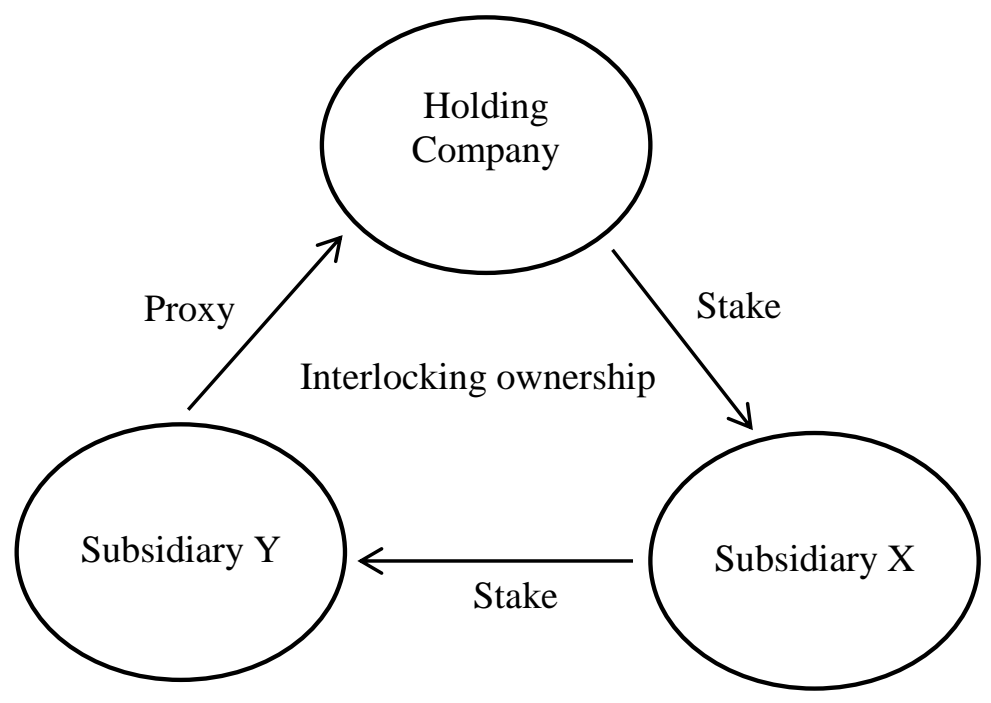

Source: An illustration created by Author. 
The early establishment of PETRONAS as a government trusteeship for the petroleum industry had distanced its role from UMNO's investment arms due to capability issues. The consideration was that Bumiputera lacked experience in critical competency and technical skills in various segments of industries such as in mining, manufacturing and construction. PETRONAS focused on government's early priority for Bumiputera to gain knowledge and experiences from FOC's operational skills in the petroleum industry. ${ }^{64}$ Transfer of technology and knowledge were getting more attention to support NEP programme by leveraging potential business in petroleum industry through PETRONAS. Consequently, a knowledgeable Bumiputera workforce in the petroleum industry had expanded Malay ownership in the transfer of equity into the ruling party's investment arms such as Fleet Holdings and Hatibudi Holdings by using interlocking stake of ownership in government-owned companies which had a reputation in construction or mining industry including oil and gas sectors.

The purpose of forming Fleet Holding in the early 1970s was for investment and acquisition to take over foreign equity in Malaysian government-owned media when the youth wing of the governing party, UMNO Youth, had protested strongly against foreign control over the Straits Time media group by Singapore corporate offices. ${ }^{65}$ Fleet through Razaleigh's negotiation succeeded in taking over a major share in Straits Times when he was asked to do so by the then Prime Minister, Tun Razak. The purchase of Strait Times equity succeeded, and the company was renamed the New Straits Times Press (NSTP). Since Razaleigh was the chairman of Fleet Holdings in 1977 until 1982, Fleet's chief business profits were solely from publishing, banking and insurance activities. ${ }^{66}$ Such activities did not contribute much to elevate Malays' knowledge and competency in manufacturing and mining industries which industries may help them to garner specific skills in the petroleum industry.

However, after Daim Zainuddin's appointment as chairperson of Fleet Holding by the then Prime Minister, Mahathir Mohamad who decided to remove Razaleigh from his chairman position, Fleet Holdings invested in other business areas such as construction and manufacturing. ${ }^{67}$ Mahathir wanted to involve Fleet Holding in diverse business activities instead of just the publishing business in line with his ambition for the industrialisation and privatisation policy. By mid-1980, the number of companies in Fleet Holdings had almost doubled, and the company had become a vast conglomerate encompassing property, hotels, print and electronic media, construction, telecommunication, retailing, plantations, banking, insurance and management services. ${ }^{68}$

Fleet Holdings acquired new business exposure for new critical skills in engineering and construction through its subsidiary Fleet Development Sdn Bhd. The company secured concessions from government's trustee agency such as the Urban Development Authority (UDA). In the mid-1980s, unfortunate business for Fleet Holding after incurred operating loss due to property market collapse in 1986. Its subsidiary, Fleet Development proved to be a loss of RM19 millionand affected mainly from its hotel business, Faber Merlin which resulted in other business sectors not performing well in such areas as the mining and petroleum industry. ${ }^{69}$ When UMNO realised that its investment arm was limp because of huge debt and losses, UMNO leaders started to raise capital fund into newly setup UMNO's investment arm known as Hatibudi while UMNO began to retreat its corporate liability. Hatibudi had shown success compared to Fleet Holdings in penetrating various business segments, especially in the mining and construction industry through acquisition in a publiclylisted company, United Engineers (M) Berhad (UEM). ${ }^{70}$ 


\section{PETRONAS’ Interlocking Directorship for Malay Equity}

The trustee mainly dominated by politicians who would use the means of proxies or nominees through director positions in the trusteeship agencies by allowing UMNO's investment company to acquire share capital or contracts offered by government agencies. A well-known UMNO politician who had a close connection with PETRONAS interest in the early establishment of PETRONAS was Tengku Razaleigh Hamzah. He held the number 3 post, the vice president of UMNO in 1975, and his victory during the party election held in June 1975 signified the victory of the main enforcers of the NEP. ${ }^{71}$ He became one of the top leaders of the party while serving as the President of PETRONAS, the president of the Malay Chambers of Commerce and Industry of Malaysia and the chairman of PERNAS, a governmentowned company as sole trusteeship and shareholder to PETRONAS, was performing a triple function as the top spokesperson, policymaker, and policy enforcer for Malays. ${ }^{72}$ The trustee-nominee practice was also applied by PETRONAS when Hatibudi Holding, the then UMNO's conglomerate after the collapse of Fleet Holding was burdened with heavy debt, through its subsidiary, United Engineers Malaysia (UEM), had awarded PETRONAS project in gas contract to MMC, a subsidiary of UEM. UEM's well-known involvement in government concession was the North-South highway project awarded to Hatibudi-controlled UEM which according to Peter Searle it was the notable example of such 'privatisation' had clearly shown the often incestuous nature of the relationship between the government and the party. ${ }^{73}$

Besides the North-South highway contract, UEM was awarded a string of highly profitable petroleum contracts. In 1987, UEM was part of a consortium that was awarded the RM47.5 million Peninsular Gas Utilisation management consultancy project in Terengganu. ${ }^{74}$ In 1991, another allocation of gas contract with a massive RM800 million gas distribution project by PETRONAS to MMC and another private Bumiputera company, Shapadu, rather than UEM, was an example of the considerable influence wielded by trustee-nominees or directors through interlocking directorships. ${ }^{75}$ Again, the award of RM800 million gas distribution projects by PETRONAS to MMC was through the decision of Malay directors or proxies from UEM. ${ }^{76}$ An illustration for an example of gas distribution project through interlocking directorship as described in Figure 3. This example of the award was inline for the Malay capitalists to ensure in achieving the government's objective in the National Petroleum Policy of 1974 with 'consent' of the NEP to acquire more equity in the petroleum industry as substituted under the mining industry. This implementation succeeded through the establishment of PETRONAS by distributing contracts to the Malay ruling elites' companies whether owned by the government or Malay political party. The realisation has been taking place with a diverse effort of political party and government companies or so-called trustee-trusteeship relationship since the 1970s to penetrate the tin and petroleum mining industry. 
Figure 3: Example of Interlocking Directorship through PETRONAS

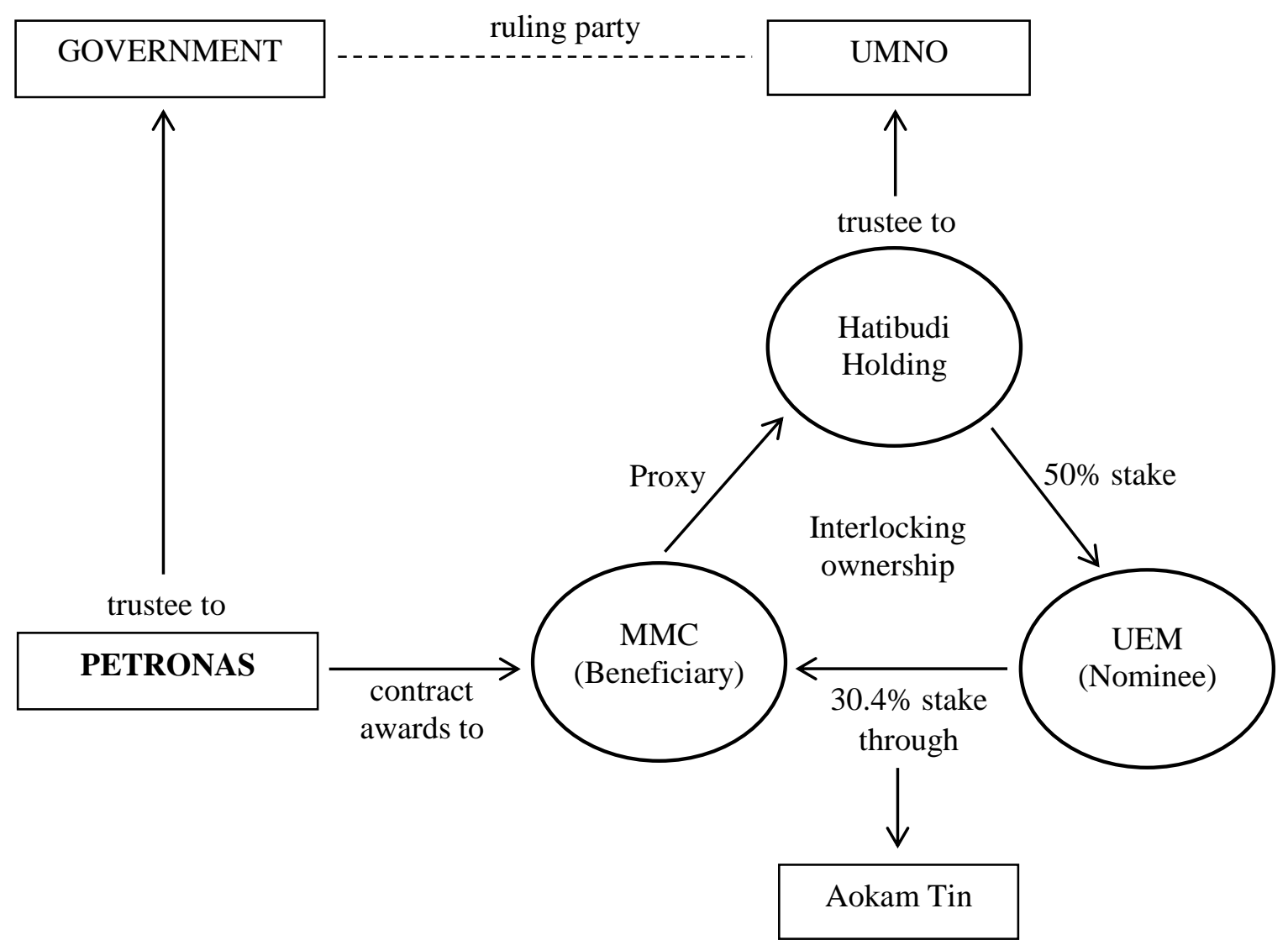

Source: An illustration created by Author.

\section{Business Partnership in Petroleum Industry \\ Inter-Ethnic Partnership in Petroleum Business}

Malay strategies to dominate equity in the mining industry as a general platform in the petroleum industry may not have succeeded if government-owned companies or government agencies control or totally owned a market share in the petroleum business. Return on investment would not gain substantial profit when business operation concentrates on ones owned capability. The approach to dominate market share, the company should seek a business partnership to establish a total solution for end business result. This approach is a multi-strategy for creating alternatives to doing business. This means that Malays, through a government-owned company or UMNO's investment arms, cannot depend on their resources. They sought partnerships in petroleum business.

BarisanNasional-led government applies power-sharing coalition to ensure stability and harmony in demands of specific interest by multi-culture society. In the economic field, UMNO also practised profit sharing gain to ensure fairness of economic cake between races. There were number of PETRONAS contracts awarded to government-owned or individual Bumiputera companies had created a business 
partnership between Malays and Chinese. ${ }^{77}$ In reality, the Malay ownership in the petroleum industry had also cascaded into Chinese and Indian communities in the form of subsidies, sub-contracts and employment. Following implementation of the NEP, although this policy was in favour of Malay special privileges, Chinese equity had continued to grow. Chinese equity had doubled from $22.8 \%$ in 1969 to $45.5 \%$ in $1990 .^{78}$ Despite this achievement, however, there was an increasing need for them to come to accommodate with the government to continue expansion. ${ }^{79}$

According to Gomez, during the implementation of NEP, inter-ethnic business partnerships were common at three different levels. ${ }^{80}$ First, among the largest enterprises, prominent Malays with a background in politics or the civil service were appointed as company directors, mainly to serve as avenues to secure access to the government or bypass bureaucratic red-tape in government. ${ }^{81}$ Most of the directors had equity ownership, but they were not actively involved in the management and development of the companies. Second, at the level of the small and medium-scale enterprise (SMEs), the 'Ali-Baba' relationships were established, but there was an unequal relationship between the partners involved. ${ }^{82}$ In such ties, the Malay (sleeping) partner would be responsible for securing a contract or licence from the government, while the Chinese partner would implement the project. Third, among a few Malaysian elites, business partnerships were forged on an equal basis. ${ }^{83}$

Among the most prominent partnerships established in the early 1980s include those between the well-connected lawyer, Ibrahim Mohamad, and Brian Chang in Promet Berhad, a construction and oil exploration firm. Unfortunately, the company disintegrated almost as rapidly as it emerged as a leading quoted enterprise because of a bitter dispute between the partners, which resulted in the expulsion of Ibrahim from Promet. ${ }^{84}$

The Malay entrepreneurs bred from Mahathir's privatisation project were in the beginning groomed by inter-ethnic partnership business. Their share capital gained from this partnership was expanded into petroleum business ventures. Shamsuddin Kadir, the owner of Sapura Kencana Petroleum Berhad, had set up Sapura Holdings, ${ }^{85}$ a telecommunication company prior to his thriving business in the petroleum industry resulting from his working relationship with Eric Chia in the United Motor Works (UMW), the holder of the Toyota franchise and distributor of heavy equipment. ${ }^{86}$ In the beginning of the growth of Shamsuddin's business venture into oil and gas industry through Sapura Holdings, he then took over Crest Petroleum which was owned by Halim Saad who had 38\% share capital in the company through Renong Berhad. Later, Sapura Kencana Petroleum acquired Petcon Sdn Bhd, a former subsidiary of UEM, which obtained a number of drilling contract awards from PETRONAS Carigali.

By the mid-1990s, a number of huge publicly-listed conglomerates owned by the Chinese had a well-connected relationship with Malays who were given the directorship shareholding of the companies. Raja Tun Mohar Raja Badiozaman, the then chairman of PETRONAS, had interlocking directorate in YTL Power International which was owned by Francis Yeoh. ${ }^{87}$ YTL Power gained profitable income from independent power producer contract issued by Tenaga Nasional. However, gas produced by PETRONAS bought by YTL whose bigger market share in power generation industry had acquired lower market price due to the gas being subsidised by PETRONAS. A former PETRONAS' Chinese employee, Tan Sri Ngau Boon Keat, an engineer during the foundation of PETRONAS, set up the oil and gas company, Dialogue Group. ${ }^{88}$ The company permitted minority share capital for Kamaruddin Mohd Nor, a political confidante to Anwar Ibrahim, as an interlocking directorate. ${ }^{89}$

Wan Azmi Wan Hamzah, a protégé of Daim Zainuddin during his managerial position in Paremba, had a close business venture with T. K. Lim, an 
owner-director of Kamunting Corporation and its associated firm, Bandar Raya Developments. ${ }^{90}$ Both companies were part of the Multi-Purpose Holdings Group. Lim also sits on the Board of Land \& General, controlled by Wan Azmi Wan Hamzah, in which he also had an interest. ${ }^{91}$ Wan Azmi accumulated share capital from his controlled-companies, resulting from a business partnership with Chinese, and owned Rohas-Euco Industries that had also acquired business contracts from PETRONAS. ${ }^{92}$

\section{Expansion of PETRONAS Capital with Foreign Companies}

Other than a multi-ethnic business partnership, the Malays, through government-owned companies or UMNO's investment arms, built a business relationship with foreign companies. This was to ensure Malay domination in the petroleum industry through PETRONAS might distribute into a self-skill employee with knowledge and competency in high technologies of petroleum business activities. The Malays needed an external partnership that can help them to transfer knowledge and technology to PETRONAS' employees and business affiliates.

PETRONAS ownership in capital investment was mainly on a sharing basis approach due to the incapability of technical know-how in exploration, production and petrochemical sectors. One of the key factors of cooperation was the huge demand and gas deposit for LNG development. PETRONAS sought capital cooperation with FOC to develop partnership venture to expect a return in capital investment with foreign ownership. In the early 1980s, Malaysia was one of the seven LNG-producing nations in the world. Malaysia first joined the ranks of other LNG exporters in January 1983, when the first shipment of LNG was flagged off from the MLNG plant in Tanjung Kidurong, Bintulu. ${ }^{93}$ The LNG plants converted the abundant natural gas offshore Sarawak into liquid form for sale to a major LNG market, Japan.

Natural gas was first discovered in substantial quantities in Sarawak in the early 1970s. A proposal was made to implement an LNG project to utilise this gas for foreign exchange gain. On 31 March 1978, PETRONAS signed a joint-venture agreement with Shell and Mitsubishi, to undertake the project implementation. A company known as Malaysia LNG Sdn Bhd was formed to construct, own and operate the LNG plant. PETRONAS owns $65 \%$ of the equity with Shell and Mitsubishi each owning $17.5 \%$ respectively. ${ }^{94}$

When most of the Malaysian Continental Shelf and part of the land acreages were covered by seismic and well data which allow for assessment of the hydrocarbon potential in offshore of Sabah, Sarawak and the Malay Peninsula, two exploration blocks were offered for bidding in 1980, both located offshore Sarawak. A production sharing contract was signed with Elf Aquitaine for one of the blocks in November 1982. Under this contract, Elf acquired 8,000 kilometres of new seismic data and drilled six wells with a total expenditure of RM117 million. ${ }^{95}$ Others partners in this venture were acquired $30 \%$ of share capital by Japan Sarawak Petroleum and the remaining other $39 \%$ share capital were acquired mostly by Bumiputera-related companies which Promet Berhad owned 20\% shares, PETRONAS Carigali owned $15 \%$ shares and Delcom Services Sdn Bhd owned $4 \%$ shares. $^{96}$

Three more blocks were offered for bidding in 1982, one located in offshore Sarawak and two in eastern Sabah. Negotiation for exploration had taken placed with Samsung Corporation of Korea in joint-venture with Husky Oil of Canada for Block 7A in Sarawak. ${ }^{97}$ Areas had also been allocated for exploration by PETRONAS Carigali. Block PM6 in Peninsular Malaysia was awarded to PETRONAS Carigali in 1982, where Carigali had made one significant oil discovery at Dulang and three other minor oil and gas discoveries at Beranang, Resak and Meranti. ${ }^{98}$ 
In the late 1980s, PETRONAS viewed the petrochemical industry as the most modern profile industry which brought intangible benefits for PETRONAS. More than any other sector of the petroleum business, petrochemical have necessitated joint ventures with foreign interests. In 1989, BASF of Germany incorporated themselves in Malaysia in venturing with PETRONAS. ${ }^{99}$ Ali Yasin was in charge of the PETRONAS team that had led to the establishment of BASF in Malaysia. BASF had 160 expatriates stationed at Gebeng representing nine different nationalities, and employing 500 Malaysians. ${ }^{100}$

BASF-PETRONAS jointly ventured with BP Company to own Ethylene Malaysia Sdn Bhd (EMSB) and Polyethylene Malaysia Sdn Bhd (PEMSB). EMSB and PEMSB are based on the same site in Kerteh. The initial USD800 million investment was for a $320,000 \mathrm{bpd}$ ethane cracker and a 200,000 bpd polyethylene plant utilising BP's technology. ${ }^{101}$ In 1987, both plants were expanded to 400,000 bpa and 250,000 bpa respectively. BP has a 15\% share in EMSB with PETRONAS having a $72.5 \%$ share and Idemitsu $12.5 \%$. In PEMSB, BP has a 60\% stake, PETRONAS 40\%. ${ }^{102}$

The government-owned company did not rely only on PETRONAS contracts. To expand business revenue for other business sector opportunities, they moved into an external competition to acquire oil and gas jobs offered by international oil companies. This created capital expansion in the hand of Bumiputera ownership outside PETRONAS. In November 1990, UEM moved into the oil and gas industry when it received a RM40 million drilling contract from Esso Production Malaysia Inc. The contract was to be undertaken by UEM's subsidiary, Petcon Sdn Bhd. ${ }^{103}$ However, this case of external competition on oil contract offered by foreign companies besides PETRONAS was a minor correlation between PETRONAS' contribution towards Malay equity because the impact on Malay ownership in the petroleum industry was still marginal given the subsidiaries were sharing interests between Malays and nonMalays.

\section{PETRONAS’ Equities in Government-Owned Corporations}

The Malaysian government established and mobilised various delivery platforms or mechanisms to ensure that the NEP objectives were attained at 'all cost and resources'. Government trust agencies and a growing number of governmentlinked companies (GLC) began participating in business activities as a means to increase Bumiputera share of corporate equity. With increased public expenditure, trust agencies and GLC went on an acquisition drive, aided by a 1975 government ruling that each quoted firm had to ensure a minimum $30 \%$ of its equity was allocated to Bumiputera agencies or individuals. Government-linked organisations usually acquired about $20 \%$ to $50 \%$ of the equity in companies for investment purposes. ${ }^{104}$

Using PETRONAS as a platform of GLC, the government took the step of increase Malay equity towards changing the ownership structure of many of the large government-owned corporations. This structural change was through corporatisation, which started in the mid-1980s with the listing of Malaysian International Shipping (MISC), Malaysian Airlines (MAS), Tenaga Nasional Berhad (TNB) and Heavy Industries Corporation of Malaysia (HICOM) of which later in the 1990s, PETRONAS had established its business expansion for capital investment and equity ownership in these companies. ${ }^{105}$

In the late 1980s, PETRONAS was considered one of the main revenue contributors to the government. Total gas production had more than doubled since the 
decade of the late 1970s. From 1983 to 1987, PETRONAS contributed total cash to the government in term of royalty, income tax and dividend were amounted to RM34.2 billion. ${ }^{106}$ Oil royalty to the government was about to RM466 million in 1988 and, in total contribution, PETRONAS generated cash to the Federal Government amounting to RM5 billion in the same year. For the financial year 1988 and 1989, PETRONAS earned a profit after tax amounting to RM2.3 billion and RM2.4 billion. ${ }^{107}$ Since 1986 to March 1989, PETRONAS had been making a substantial investment in Bank Bumiputera Malaysia Berhad (BBMB). However, in December 1989, BBMB had implemented capital restructuring in which RM1.4 billion of PETRONAS's investment had divested. ${ }^{108}$

Figure 4: PETRONAS Ownership in the late-1980s

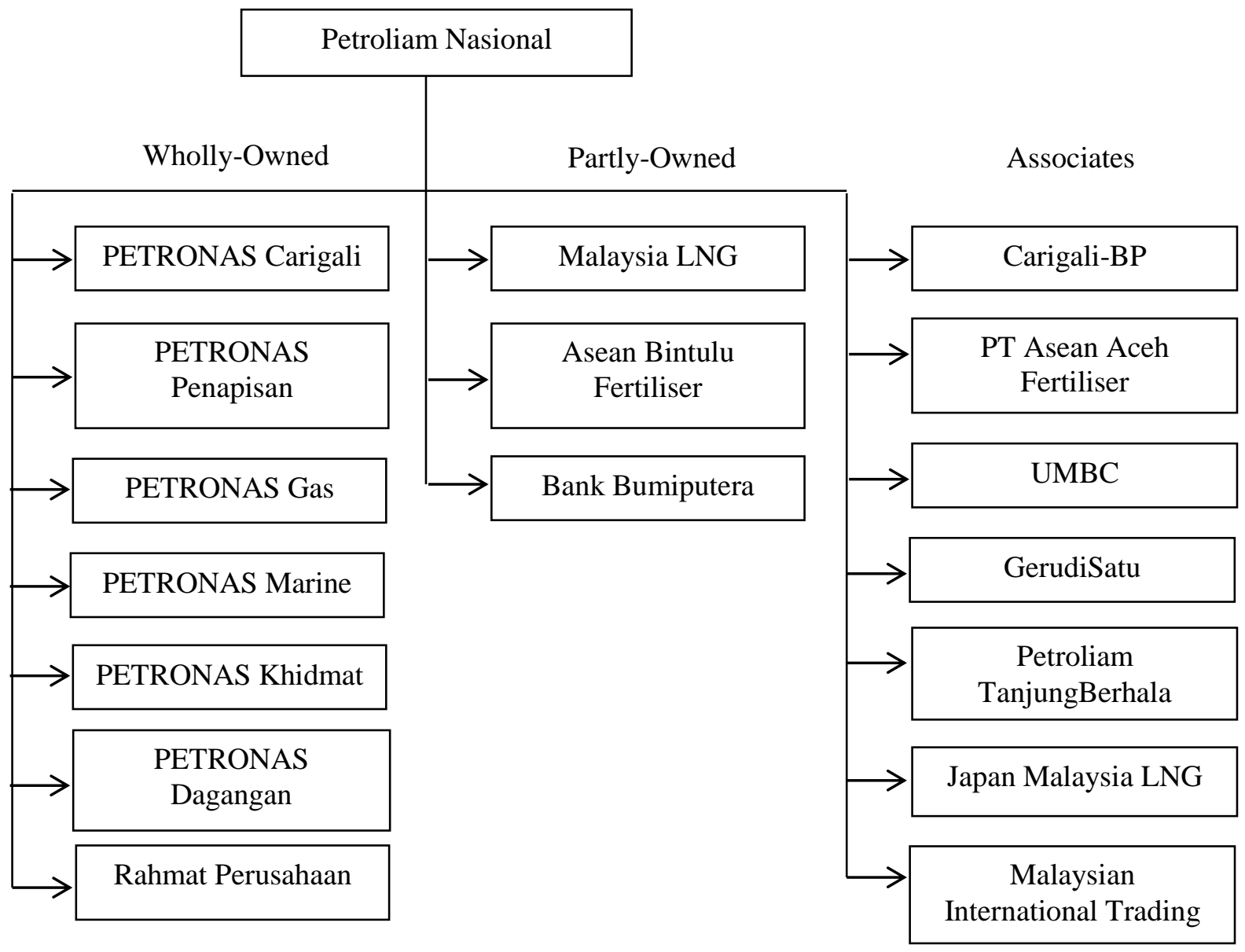

Source: Major Companies of the Far East \& Australasia 1990/91: Volume 1

\section{Petroleum Business in Emerging Market Countries \\ PETRONAS Increased Bumiputera Equity}

The petroleum industry in Malaysia emerged as a saviour industrial sector for Bumiputera at the time when the government was looking to achieve 30\% Bumiputera equity in the implementation of the New Economic Policy (NEP). When the oil and gas sector started to contribute substantially to government income, many individual 
Bumiputera had benefited from this economic development. Government through PETRONAS and other trust agencies divested their share capital and profit for business investment in other subsidiary companies such as PETRONAS Gas, PETRONAS Dagangan, PETRONAS Carigali and so forth. The investment resulted in increasing Bumiputera equity in the stock market. The ownership of share capital, the representatives of Bumiputera directors in public listed companies and the increase of Bumiputera employees in the corporate sector had contributed in closing the gap in the economic cake between Bumiputera and non-Bumiputera.

In the first 20 years of NEP implementation, the business elite had changed the capital ownership landscape from one dominated by foreigners and local Chinese to a selected group of politically well-connected Bumiputeras and non-Bumiputeras. Statistics on ethnic ownership of share capital in the corporate sector between 1970 and 1990 reveal that the Bumiputera share has risen almost tenfold, from a low $2.4 \%$ in 1970 to a remarkable $20.3 \%$ in 1990 , though such a figure still falls considerably short of the NEP's $30 \%$ target. Of this $20.3 \%$ worth RM22.3 billion in par values, $14 \%$ was held by Bumiputera individuals and the rest by trust agencies as shown in Table $11 .^{109}$

Table 1: Ownership of Share Capital, 1970-90 (percentages)

\begin{tabular}{|l|c||c|}
\hline \multicolumn{1}{|c|}{ Ownership Category } & $\mathbf{1 9 7 0}$ & $\mathbf{1 9 9 0}$ \\
\hline \hline Bumiputera Individuals & 1.6 & 14.0 \\
\hline Bumiputera Trust Agencies & 0.8 & 6.3 \\
\hline Chinese & 27.2 & 44.9 \\
\hline Indians & 1.1 & 1.0 \\
\hline $\begin{array}{l}\text { Other Non-Bumiputera } \\
\text { Malaysian }\end{array}$ & - & 0.3 \\
\hline Foreign Residents & 63.4 & 25.1 \\
\hline \hline Nominee Companies & 6.0 & 8.4 \\
\hline \hline
\end{tabular}

Sources: Second and Sixth Malaysia Plan

Distribution of share capital does not indicate actual ownership, though the predominant owners of corporate stock were Chinese and foreigners. The actual ownership of share capital always signifies the Bumiputera politicians are among those who have resorted to the use of nominee companies as a means to interlock minority shareholders. ${ }^{110}$ There is also evidence of Bumiputera ownership through foreign domiciled companies. One example of this is the case of a Hong Kong based company, Yung Pui Co., controlled by Basir Ismail and Wan Azmi Hamzah. The company had a stake in publicly-listed Cycle \& Carriage Ltd, which in turn has an interest in other listed entities such as Cycle \& Carriage Bintang and Cold Storage. ${ }^{111}$

It was also a belief that substantial achievement made by individual Bumiputera and trust agencies such as PETRONAS and HICOM, with the availability of vast resources of government enterprises, had discovered that capitalised Bumiputera equity on the bourse amounted to $34.5 \%$ in $1988 .{ }^{112}$ This indicates that the economic restructuring especially assisted by government's privatisation plan as a whole has achieved more than the target aspirations of the NEP. Other than that, all limited companies listed in KLSE in 1985 had shown that the ownership pattern by limited companies with revenue amounted to 5 million and more in major industries such as petroleum, plantation, construction, retail and so forth. Indicates that companies' 5 million revenue and above represent only $30 \%$ of a total number of limited companies with annual revenue of RM1 million and above, they account for 
$83 \%$ of total revenue, $80 \%$ of total assets and $70 \%$ of total employment in the corporate sector.

The use of public share issues as a means of asset sales has played a significant role in the transfer of public assets to government trust agencies and individual Bumiputera. Proceeds from public sales totalled RM216.4 million out of a total of RM437.6 million, including the two largest sales up to mid-1990, MISC (one of the significant subsidiaries of PETRONAS) and MAS. ${ }^{113}$ Among PETRONAS's subsidiaries emerged in the top 100 KLSE companies were PETRONAS Gas, PETRONAS Dagangan and MISC.

Minority shareholders in PETRONAS' subsidiaries substantially owned by Malay businessman can be manipulated to issue higher shares to interlock their private equities through the directors that represented those companies such as Mohd Hassan Marican, Yahya Ismail and Mohd Ali Yasin. Another director in proxy for PETRONAS was Raja Tun Mohar Raja Badiozaman who was the director in YTL Corporation and YTL Power International. ${ }^{114}$

\section{PETRONAS' Capital Investments}

The capital investment made by PETRONAS in upstream and downstream sectors amounting to contracts valued at RM8.9 billion in 1990 had managed to the uplift socio-economic mobility of Bumiputera from limited resources, expertise and share capital to the emerging market of unlimited talent and capital mostly brought by foreign companies into the market of the Malaysian petroleum industry. PETRONAS started divesting its capital to establish PETRONAS Carigali in 1978. The form of investment was inclining towards joint venture partnership whereby PETRONAS forwarded partial capital of total investment to foreign companies that possessed expertise and equipment in exploration and production. Some 225 assessment exploration deposits had been drilled between 1977 and 1982 by contractors of PETRONAS with foreign companies and throughout this period, 25 oil deposits and 27 gas deposits were found. Also, between 1980 and 1982, PETRONAS Carigali had drilled ten assessment exploration deposits which were all successful oil and gas deposits in offshore Terengganu. ${ }^{115}$

PETRONAS took several steps to give incentives to foreign companies carrying out petroleum exploration in Malaysia. This included several incentives put into the production sharing contract which had been introduced by the government in 1985 to encourage foreign companies and investors. The contracts were highly participated and within two years in 1986 and 1989, there was 21 production sharing contracts signed with FOC, in which the investment amount had reached more than RM880 million. ${ }^{116}$ Since production sharing contract has introduced in 1976, the invested capital yielded by a foreign investor into exploration and production activities were amounting to RM22.2 billion in 1989. ${ }^{117}$ PETRONAS spent about RM4 billion for exploration activities. These expenses included the development works for Dulang and Siligi oil fields in Terengganu offshore and Central Luconia in Sarawak offshore.

Exploration also took place in the west cost of the Malay Peninsula where the area called Block PM 1 was situated in offshore of Perlis, Kedah, Pulau Pinang and Perak. Regarding geological area, this block situated on the east side of Lembangan Sumatera Utara, which area expected to produce oil. The production sharing contracts were established with Sun Malaysia Oil Company, Champlin Malaysia Incorporated and PETRONAS Carigali in December 1987. ${ }^{118}$ Sun Malaysia was owned by Sun Exploration, and Production Company of America and Champlin Malaysia Incorporated was owned by Champlin International Petroleum Company and Kerr- 
McGee Malaysia Corporation. ${ }^{119}$ However, when the drilling was performed into oil deposit in Jun 1989, there was no potential hydrocarbon found in the area. The consortium had invested an amount worth RM23.75 million. ${ }^{120}$

In August 1988, an offshore area of Kelantan which called Block PM 2 was given to the consortium consisting of Home Oil Malaysia Ltd., Petro-Canada Malaysia Inc., Texaco Canada Malaysia Inc., PEXCO N. V. and PETRONAS Carigali in putting effort for exploration and production activities under the production sharing contract. ${ }^{121}$ Under this contract, the consortium had expensed RM43 million for exploration within three years. ${ }^{122}$

The consortia for exploration activities were a kind of 'sleeping partner' business for PETRONAS with FOC through PETRONAS Carigali. Even though PETRONAS did not have expert engineers in the fields, under the contract the company should take understudy approach to support the Malaysianisation Programme. Under this programme, each FOC required that all positions held by them should have one Malaysian to perform understudy that they would transfer expertise in future.

In 1982, PETRONAS concluded two contracts with Tokyo Electric Power and Tokyo Gas for selling and delivery of LNG until 2003. The export of Malaysia LNG to Japan almost covered the entire output in Bintulu gas fields; under these contracts and another contract signed in 1990, to supply Saibu Gas of Fukuoka in southwestern Japan, for 20 years from 1993. In the mid-1980s, Malaysia LNG was becoming the third largest producer of LNG in the world when the first phase of the Gas Utilisation Project was completed in $1985 .^{123}$

PETRONAS expanded business in the refinery and trading sector in 1983. It initiated the construction of refineries Kertehand later in Melaka to reduce its dependency on Royal Dutch Shell's two refineries in Port Dickson and Esso's refinery in Sarawak. These two majors, and other foreign companies, already covered much of the domestic retail market, but the new subsidiary PETRONAS Dagangan was given the initial advantage of preference in station location. By 1990, 252 service stations carried the PETRONAS brand, all but 20 on a franchise basis, and another 50 were planned. ${ }^{124}$ Some were set up on the grounds of social benefit rather than of strict commercial calculation.

\section{Distribution of PETRONAS' Investments to Bumiputera}

At the end of the 1980 s, petroleum equity owned by Bumiputera during 'the age of establishment' of PETRONAS was unsatisfactory because the bigger part of investments involved upstream business where exploration and production activities required high-level expertise and none of the Bumiputera companies had those skills. Therefore, most of the investment form was a kind of joint-venture strategy. In 1988, from 11 foreign businesses that operated in upstream and downstream sectors, only three companies had equity owned by Bumiputera. As for these three Bumiputera companies the equity owned amounted to RM32.4 million or about $9.7 \%$ of RM333.5 million on paid-up capital of the companies. ${ }^{125}$ Apart from equity ownership, Bumiputera participation in the petroleum industry may also be seen from other aspects such as engagement in marketing activities and participation in contract works offered by foreign companies. Up to the year 1988, oil companies had appointed about 1,800 petrol pump operators in which 714 or $39.4 \%$ of total operators consisted of Bumiputera owners. ${ }^{126}$ Regarding distribution of petroleum related products, some 4,168 distributors were Bumiputera owned. ${ }^{127}$

From 1980 to 1987, PETRONAS had offered a number of contracts in the upstream sector with values of RM8.6 billion. From this amount or $44 \%$ were offered 
to Bumiputera companies. In the downstream sector, oil companies had offered contracts with values amounting to RM276 million. ${ }^{128}$ From this amount, $31 \%$ or RM86 million were offered to Bumiputera companies. ${ }^{129}$ Until December 1989, PETRONAS extended investment in petroleum-related developments in an upstream and downstream sector which consist of the following listed projects below with distribution of contract values to foreign, ${ }^{130}$ Bumiputera and non-Bumiputera companies are shown in Table 2.

I. Oil refinery in Lutong, Port Dickson, Kerteh and Malacca

II. Malaysia Liquefied Natural Gas (MLNG) Bintulu

III. ASEAN Bintulu Fertiliser

IV. Hot Briquetted Iron and Methanol Plant in Labuan

V. Peninsular Gas Utilisation Project Phase I and II

VI. Ethylene in Kerteh

VII. Polypropylene in Johor

VIII. Middle Distillate Synthesis in Bintulu

IX. Aluminium Smelting in Bintulu

X. Shell

XI. Esso

XII. Other Production Sharing Contractors (PSC Contractor)

Table 2. Distribution of Contracts' Values to Foreign, Bumiputera and NonBumiputera

\begin{tabular}{|c|c|c|c|c|c|}
\hline No. & Project & $\begin{array}{l}\text { Investment } \\
\text { as at } 31 \text { Dec. } \\
1989 \\
\text { (RM million) }\end{array}$ & $\begin{array}{l}\% \text { of } \\
\text { Distribution } \\
\text { to Foreign } \\
\text { Company }\end{array}$ & $\begin{array}{l}\% \text { of } \\
\text { Distributio } \\
\text { n to } \\
\text { Bumiputera } \\
\text { Company }\end{array}$ & $\begin{array}{l}\% \text { of } \\
\text { Distribution } \\
\text { to Non- } \\
\text { Bumiputera } \\
\text { Company }\end{array}$ \\
\hline i. & 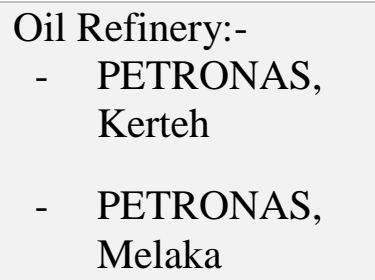 & $\begin{array}{c}360 \\
96\end{array}$ & $\begin{array}{l}96 \% \\
41 \%\end{array}$ & $\begin{array}{l}2 \% \\
16 \%\end{array}$ & $\begin{array}{c}2 \% \\
43 \%\end{array}$ \\
\hline ii. & $\begin{array}{l}\text { Malaysia Liquefied } \\
\text { Natural (MLNG) } \\
\text { Gas Bintulu }\end{array}$ & 3,281 & $89 \%$ & $9 \%$ & $2 \%$ \\
\hline iii. & $\begin{array}{l}\text { ASEAN Bintulu } \\
\text { Fertiliser (ABF) }\end{array}$ & 600 & $90 \%$ & - & $10 \%$ \\
\hline iv. & $\begin{array}{l}\text { Peninsular Gas } \\
\text { Utilisation Project } \\
\text { - } \quad \text { Project I } \\
\text { - } \quad \text { Project II }\end{array}$ & $\begin{array}{c}462 \\
1,037\end{array}$ & $\begin{array}{l}93 \% \\
69 \%\end{array}$ & $\begin{array}{l}2 \% \\
26 \%\end{array}$ & $\begin{array}{l}5 \% \\
5 \%\end{array}$ \\
\hline v. & $\begin{array}{l}\text { Methyl Tertiary } \\
\text { Butyl Ether (MTBE), } \\
\text { Kuantan }\end{array}$ & 37 & $33 \%$ & $16 \%$ & $51 \%$ \\
\hline vi. & $\begin{array}{l}\text { Polypropylene, } \\
\text { Kuantan }\end{array}$ & 32 & $75 \%$ & $9 \%$ & $16 \%$ \\
\hline
\end{tabular}




\begin{tabular}{|l|l|l|l|l|l|}
\hline vii. & Contractors for PSC & 27,880 & $38 \%$ & $54 \%$ & $8 \%$ \\
\hline viii. & Total & 33,785 & & & \\
\hline
\end{tabular}

Source: Penyata Rasmi Parlimen 1990

Total investments for the refinery plant owned by Shell in Lutong and Port Dickson and owned by Esso in Port Dickson were RM937 million. ${ }^{131}$ However, information regarding contract distribution for Shell and Esso were unavailable because the plants were developed in 1914 and 1964. The investment projects value for Hot Briqueued Iron Plant (HBI), Methanol Plant in Labuan and Middle Distillate Synthesis in Bintulu amounted to RM1,221 million. From this amount, 86\% of the contract value was given to foreign companies and another $14 \%$ to local companies. ${ }^{132}$

The government expressed dissatisfaction over the percentage of contract distribution to Bumiputera companies ${ }^{133}$ The share enjoyed by Bumiputera was discouraging because most of the projects were carried out with high technological tools in which the capability for Bumiputera in this field was still lower than foreign companies. Regarding petroleum marketing and retailing, the number of companies and businesses awarded with licences as petrol station operators to sell petroleum products until 1986 was 1,594 as shown in Table 3. From this number, 503 petrol stations or $31.6 \%$ were owned by Bumiputera and the other 1,091 petrol stations or $68.4 \%$ were operated by non-Bumiputera.

Table 3: Number and Distribution of Petrol Stations According to Bumiputera and Non-Bumiputera Ownership

\begin{tabular}{|l|l|l|l|l|l|l|}
\hline & \multicolumn{2}{|c|}{ Bumiputera } & \multicolumn{2}{c|}{ Non-Bumiputera } & \multicolumn{2}{c|}{ Total } \\
\hline & No. & $\%$ & No. & $\%$ & No. & $\%$ \\
\hline Esso & 114 & 29.5 & 273 & 70.5 & 387 & 24.3 \\
\hline Shell & 155 & 22.6 & 530 & 77.4 & 685 & 43.0 \\
\hline Caltex & 53 & 22.6 & 146 & 73.4 & 199 & 12.5 \\
\hline BP & 29 & 30.2 & 67 & 69.8 & 96 & 6.0 \\
\hline PETRONAS & 120 & 100.0 & - & - & 120 & 7.5 \\
\hline Mobil & 32 & 29.0 & 75 & 70.1 & 107 & 6.7 \\
\hline Total & 503 & 31.6 & 1,091 & 68.4 & 1,594 & 100.0 \\
\hline
\end{tabular}

Source: Penyata Rasmi Parlimen 1985

The Malays in the government expressed dissatisfaction over lower numbers of Bumiputera companies granted licences for petrol stations because the contract allocation given to them by foreign companies, instead of PETRONAS, was still below the NEP target. ${ }^{134}$ The government aggressively monitored the appointment of petrol station operators to ensure oil companies followed the NEP objectives. In this regard, oil companies were directed to abide by the NEP rules.

Until the end of 1990, PETRONAS opened 252 petrol stations throughout the country. On average, those petrol stations recorded petroleum selling about $35 \%$ higher than the average of petroleum selling by others petrol station owned by foreign companies. From 252 petrol stations in 1990, 129 stations were owned by PETRONAS and through marketing agents. Regarding operating stations, there were about 227 stations operated by sales representatives, while PETRONAS itself operated the remaining of 25 stations. 


\section{Conclusion}

The discussion on capital accumulation made by Malays through PETRONAS was the centre of capital resources in increasing Malay equity and ownership specifically in the petroleum and mining industries. PETRONAS supported this objective by consolidating its subsidiaries with government agencies and Bumiputera entrepreneurs. It was the method to uplift social mobility of the Malays and PETRONAS had realised this objective by emphasising on strategies and processes of the inter-capital relationship between PETRONAS, government agencies and Bumiputera entrepreneurs which had led to the creation of a Malay middle class.

The creation of NOC through the establishment of PETRONAS was a Malay strategy to protect the affirmative action programme using the NEP platform in a higher form of monopolisation. The power in politics and government machinery governed by UMNO had strengthened the method of capital accumulation through PETRONAS. As discussed in this article, the method used by PETRONAS through its relationship with government agencies, government-owned corporations and Bumiputera entrepreneurs was using the strategy of ownership, trusteeship, partnership and privilege.

The method of capital accumulation was an adaptation of the British colonial method of oil protectionism. It was when the British had realised that the American Standard Oil Company dominated oil marketing and distribution in the Far East and Southeast Asia. This situation led the British and the Dutch into capital partnership in Royal Dutch Shell Petroleum Company to control and protect their interests in oil exploration and production in their colonies in Southeast Asia to counter Standard Oil's access to a cheaper oil supply.

PETRONAS used the same method of protectionism when the situation had worsened Malay ownership in natural resources over mining industry platform wherein foreign companies and non-Bumiputera substantially owned the upstream and downstream activities before the promulgation of the NEP. In this situation, the main objective of PETRONAS in response to this unbalanced economic cake was to transfer capital equity and management control in oil and gas companies into the hands of Bumiputera ownership. By offering contracts and granting licences through proxy companies owned by GLCs and Bumiputera companies, PETRONAS succeeded in expanding Malay ownership from just being a businessman in manufacturing business such as in small-medium enterprise (SME) into business which involved highest risk business portfolio.

\section{Note}

* Saiful Khairi Kamarudin (khairi80@hotmail.com) is a Graduate from History Department, University of Malaya.

** Dr. Puteh Noraihan A Rahman (putehnoraihan.arahman@taylors.edu.my) is a lecturer from Taylor's University (Lakeside Campus).

\footnotetext{
${ }^{1}$ Fifth Malaysia Plan 1986-1990, Economic Planning Unit, Prime Minister's Department Malaysia. 2 "Comments on National Petroleum Advisory Council's Review of Petroleum Development Act", PETRONAS, 1975, File 276/PT.I, Arkib Negara Malaysia.
} 
3 “A Letter from J.E. Jenkins, General Manager of Shell (M) Companies to M.B. Hashim, Executive Director of PETRONAS", Bahagian Kemajuan Petroleum, JabatanPerdanaMenteri, 1976, File 276/PT.I, Arkib Negara Malaysia.

${ }^{4}$ Ibid

${ }^{5}$ Edmund Terence Gomez, Political Business: Corporate Involvement of Malaysian Political Parties, James Cook University of North Queensland, (Australia: 1994), p. 4.

${ }^{6}$ The law was revised on two major counts during TunHussien Onn's premiership. One amendment was to weaken the powers conferred upon the Minister of Trade and Industry. The second was to make the law more liberal on the definition of applicable companies. The law stated that the NEP's mandatory bumiputera equity ownership ratio would not be uniformly applied to individual companies.

${ }^{7}$ Edmund Terence Gomez, Political Business, p. 190.

${ }^{8}$ Edmund Terence Gomez, Money Politics in the Barisan Nasional, FORUM (Kuala Lumpur: 1990), p. 47.

${ }^{9}$ Ibid.

${ }^{10}$ Edmund Terence Gomez, Politics in Business: UMNO's Corporate Investment, FORUM (Kuala Lumpur: 1990), p. 10.

${ }^{11}$ Edmund Terence Gomez, Politics in Business: UMNO's, p. 10.

12 Ibid., p.11.

13 NPAC's $4^{\text {th }}$ Meeting on National Policy on Petroleum Industries, Bahagian Kemajuan Petroliam, JabatanPerdanaMenteri, 1975, File 276/PT.I, Arkib Negara Malaysia.

${ }^{14}$ Sedekat Pembangunan PETRONAS, PETRONAS, p. 46.

15"Lawyer's Letter to Chamber on 'Petroleum Development Act 1974", Malaysian International Chamber of Commerce and Industry, $6^{\text {th }}$ March 1976.

${ }^{16}$ Khai Leong Ho, "Indigenizing The State: The New Economic Policy and The Bumiputera State in Peninsular Malaysia", Doctoral Thesis, University Microfilms International, The Ohio State University, 1988, p. 227.

${ }^{17}$ PenyataRasmiParlimen, Dewan Rakyat, ParlimenKeenam, Jilid III, Bil. 22, 24 Julai 1985, p. 4085.

${ }^{18}$ Lawyer's Letter to Chamber., p. 4.

${ }^{19}$ Edmund Terence Gomez, Malaysian Business Group: The State and Capital Development in the Post-Currency Crisis Period, (Centre for Policy Initiatives: 2005), p. 119.

${ }^{20}$ Khai Leong Ho, "Indigenizing The State", p. 240.

${ }^{21}$ Jomo K.S, "Introduction", Privatizing Malaysia: Rents, Rhetoric, Realities, ed. Jomo K.S., Westview Press (Oxford: 1995), p. 28.

${ }^{22}$ Edmund Terence Gomez, Malaysian Business Group, p. 15.

${ }^{23}$ Jomo K.S, Privatizing Malaysia: Rents, Rhetoric, Realities, Westview Press (Oxford: 1995), p. 42.

${ }^{24}$ Ibid.

${ }^{25}$ Jeff Tan, Privatization in Malaysia: Regulation, Rent-Seeking and Policy Failure, Routledge, (New York: 2010), p. 53

${ }^{26}$ Ibid., pp. 53-55.

${ }^{27}$ Zulkifli Idris, Privatization in Malaysia: A Case Study of the Impact of Privatization on Privatized Public Agencies, University of Southern California, (California: 1995), p. 67.

${ }^{28}$ Edmund Terence Gomez, Corporate Equity Distribution: Past Trends and Future Policy, Centre for Public Policy Study, (Kuala Lumpur: 2005), p. 4.

${ }^{29}$ Fifth Malaysia Plan 1986-1990, Economic Planning Unit, Prime Minister's Department Malaysia, p. 315 .

${ }^{30}$ Edmund Terence Gomez, Corporate Equity Distribution, p. 8.

31 Edmund Terence Gomez, Enterprise Development and Inter-Ethnic Relations in Malaysia: Affirmative Action, Generational Change, and Business Partnerships, (Centre for Policy Initiatives: 2005), p. 8.

${ }^{32}$ Jomo K. S. and Tan WooiSyn, Privatization And Renationalization In Malaysia: A Survey, (Kuala Lumpur: 1995), p. 24.

${ }^{33}$ CIC (Capital Issues Committee) is another industrial legislation set in favour of bumiputera preferential treatment like the Industrial Coordination Act (ICA) but stated implicitly for bumiputera's substantial portion of share like ICA. Its purpose is to examine application by public companies in the issues of shares in Malaysia and in the Kuala Lumpur Stock Exchange (KLSE). All such activities have to be approved by the committee comprises the Governor of Bank Negara, Secretary General in the Ministry of Trade and Industry and Registrar of Companies. CIC's guideline accord priority to a special issue of shares to bumiputera investors approved by the Ministry of Trade and Industry in accordance with Government directives and the NEP. The issue of share price would be determined after considering profitability, dividends, net tangible assets value and the market price 
of the shares.

${ }^{34}$ Edmund Terence Gomez, Political Business, p. 111.

${ }^{35}$ Ibid., pp. 157-158.

${ }^{36}$ Edmund Terence Gomez, Enterprise Development, p. 9.

${ }^{37}$ Ibid.

${ }^{38}$ Rugayah Mohamed, "Public Enterprises", Privatizing Malaysia: Rents, Rhetoric, Realities, ed. Jomo K.S., Westview Press, (Oxford: 1995), p. 68.

${ }^{39}$ Ibid.

${ }^{40}$ Edmund T. Gomez and Jomo K.S., Malaysia's Political Economy: Politics, Patronage and Profits, Cambridge University Press, (Cambridge: 1997), p. 81.

${ }^{41}$ Ibid., p. 87.

${ }^{42}$ PenyataRasmiParlimen, Dewan Rakyat, ParlimenKelima, Jilid III, Bil. 32, 21 Oktober 1981, p. 4102.

${ }^{43}$ PenyataRasmiParlimen, Dewan Rakyat, ParlimenKetujuh, Jilid IV, Bil. 24, 22 Jun 1990, p. 4984.

44 Ibid.

${ }^{45}$ Jomo K. S. and Tan WooiSyn, Privatization And Renationalization, p. 40.

${ }^{46}$ Ibid.

${ }^{47}$ Edmund Terence Gomez and Jomo K. S., Malaysia's Political Economy, p. 103.

${ }^{48}$ Edmund Terence Gomez, Political Business, p. 24.

49 "Minute of $4^{\text {th }}$ Meeting of National Petroleum Advisory Council on National Petroleum Policy", Bahagian Kemajuan Petroleum, JabatanPerdanaMenteri, 1975, File 276/PT.I, Arkib Negara Malaysia. 50“'Oil Companies in Malaysia: An Uncertain Feeling", The Financial Times, 3 June 1975, File 276/PT.I, JabatanPerdanaMenteri Malaysia.

${ }^{51}$ James V. Jesudason, Ethnicity and the Economy: The State, Chinese Business, and Multinationals in Malaysia, Oxford University Press, (Singapore: 1990), pp. 84-86.

52 Bruce Gale, Politics and Public Enterprise in Malaysia, Eastern Universities Press, (Singapore: 1981), p. 117.

${ }^{53}$ Ibid., p. 118.

${ }^{54}$ Edmund Terence Gomez, Politics in Business: UMNO's, p. 12.

${ }^{55}$ Ibid., 119.

56 Ibid., 124.

${ }^{57}$ Edmund T. Gomez and Jomo K.S., Malaysia's Political Economy, p. 103.

${ }^{58}$ Edmund Terence Gomez, Politics in Business: UMNO's, p. 11.

${ }^{59}$ Khai Leong Ho, "Indigenizing The State", p. 252.

${ }^{60}$ Edmund Terence Gomez, Politics in Business: UMNO's, pp. 35-36.

${ }^{61}$ James V. Jesudason, Ethnicity and the Economy, p. 168.

${ }^{62}$ Edmund Terence Gomez, Politics in Business: UMNO's, pp.13- 14.

63 Ibid.

64 "Minute of $6^{\text {th }}$ Meeting of National Petroleum Advisory Council on Mineral Resources Development Panel: Paper on Fossil Fuels Industry", Bahagian Kemajuan Petroleum, JabatanPerdanaMenteri, 1975, File 276/PT.I, Arkib Negara Malaysia.

${ }^{65}$ Edmund Terence Gomez, Politics in Business: UMNO's, p. 52.

${ }^{66}$ Ibid., pp. 54-58.

${ }^{67}$ Edmund Terence Gomez, Political Business, pp. 67-69.

${ }^{68}$ Ibid., p. 71.

${ }^{69}$ Edmund Terence Gomez, Politics in Business: UMNO's, p. 95.

${ }^{70}$ Ibid., pp. 111-113.

${ }^{71}$ Ibid., p. 35.

72 Ibid.

${ }^{73}$ Peter Searle, The Riddle of Malaysian Capitalism, Rent-Seekers or Real Capitalist? Allen \&Uwin and University of Hawai'i Press (Honolulu: 1999), p. 119.

${ }^{74}$ Edmund T. Gomez and Jomo K.S., Malaysia's Political Economy, p. 97.

${ }^{75}$ Peter Searle, The Riddle of Malaysian Capitalism, p. 86.

${ }^{76}$ Ibid.

${ }^{77}$ Edmund Terence Gomez, Enterprise Development, p. 8.

${ }^{78}$ Edmund Terence Gomez, Malaysian Business Group, p. 123.

${ }^{79}$ James V. Jesudason, Ethnicity and the Economy, p. 147.

${ }^{80}$ Edmund Terence Gomez, Enterprise Development, pp. 4-5.

${ }^{81}$ Ibid., p. 4.

82 James V. Jesudason, Ethnicity and the Economy, p. 149.

${ }^{83}$ Ibid., p. 5. 
84 Yoshihara Kunio, The Rise of Ersatz Capitalism in Southeast Asia, Oxford University Press (Singapore: 1988), p.10.

${ }^{85}$ Edmund Terence Gomez, Enterprise Development, p. 6.

${ }^{86}$ Ibid., p. 5.

${ }^{87}$ Edmund Terence Gomez, Malaysian Business Group, p. 140.

${ }^{88}$ Ibid., p. 138.

${ }^{89}$ Ibid.

${ }^{90}$ Ibid., p. 139.

${ }^{91}$ Ibid., p. 125.

92 Edmund Terence Gomez, Corporate Equity Distribution, p. 38.

${ }^{93}$ PenyataRasmiParlimen, Dewan Rakyat, ParlimenKetujuh, Jilid III. Bil. 11, 21 Mac 1989, p. 1850.

${ }^{94}$ Ibid., p. 1851.

95 Gordon Borrows, "The Production-Sharing Contract of Malaysia, the Philippines, and Egypt", p. 88.

${ }^{96}$ Sedekat Pembangunan PETRONAS 1974-1984, p. 46.

${ }^{97}$ Ibid., p. 47.

${ }^{98}$ Ibid.

99 Paddy Bowie, A Vision Realised: The Transformation of A National Oil Corporation, Orillia Corporation SdnBhd, (Kuala Lumpur: 2001), p. 243.

100 Ibid., 244.

${ }^{101}$ Ibid., 245.

102 Ibid.

${ }^{103}$ Edmund Terence Gomez, Political Business, p. 104.

${ }^{104}$ Edmund Terence Gomez, Corporate Equity Distribution, p. 4.

${ }^{105}$ Ibid.

${ }^{106}$ PenyataRasmiParlimen, Dewan Rakyat, ParlimenKetujuh, Jilid III, Bil. 6, 14 March 1989, p. 963.

${ }^{107}$ PenyataRasmiParlimen, Dewan Rakyat, ParlimenKetujuh, Jilid IV, Bil. 24, 22 Jun 1990, p. 4984. ${ }^{108}$ Ibid.

${ }^{109}$ Second Malaysia Plan 1971-1975, Economic Planning Unit, Prime Minister's Department Malaysia.

${ }^{110}$ Edmund Terence Gomez, Politics in Business: UMMNO's, pp. 25-26.

${ }^{111}$ Edmund Terence Gomez, Money Politics, pp. 24-26.

${ }^{112}$ Fong Chan Onn The Malaysian Economic Challenge in the 1990s, p. 30.

${ }^{113}$ Jomo K.S, Privatizing Malaysia, p. 133.

${ }^{114}$ Edmund Terence Gomez, Malaysian Business Group, p. 140.

${ }^{115}$ PenyataRasmiParlimen, Dewan Rakyat, ParlimenKetujuh, Jilid III, Bil. 22, 28 Jun 1989, p. 4299.

${ }^{116}$ PenyataRasmiParlimen, Dewan Rakyat, ParlimenKetujuh, Jilid III, Bil. 16, 20 Jun 1989, p. 2897.

117 Ibid.

${ }^{118}$ PenyataRasmiParlimen, Dewan Rakyat, ParlimenKetujuh, Jilid III, Bil. 1, 7 Mac 1989, p. 48.

${ }^{119}$ PenyataRasmiParlimen, Dewan Rakyat, ParlimenKetujuh, Jilid II, Bil. 43, 4 November 1988, p. 7536.

120 Ibid.

${ }^{121}$ PenyataRasmiParlimen, Dewan Rakyat, ParlimenKetujuh, Jilid II, Bil. 5,13 Mac 1989, p. 809.

122 Ibid.

${ }^{123}$ Paddy Bowie, A Vision Realised, p. 212.

${ }^{124}$ PenyataRasmiParlimen, Dewan Rakyat, ParlimenKetujuh, Jilid IV, Bil. 1, 27 Feb 1990, p. 114.

${ }^{125}$ PenyataRasmiParlimen, Dewan Rakyat, ParlimenKetujuh, Jilid II, Bil. 10, 12 Julai 1988, p. 1740.

${ }^{126}$ Ibid., p. 1741.

${ }^{127}$ Ibid.

${ }^{128}$ Ibid.

${ }^{129}$ Ibid.

${ }^{130}$ PenyataRasmiParlimen, Dewan Rakyat, ParlimenKetujuh, Jilid IV, Bil. 13, 15 Mac 1990, p. 2602.

${ }^{131}$ Ibid., p. 2603.

132 Ibid.

133 Ibid., p. 2605.

${ }^{134}$ PenyataRasmiParlimen, Dewan Rakyat, ParlimenKeenam, Jilid III, Bil. 50, 21 November 1985, p. 7803. 


\section{Reference}

\section{Primary Sources}

Government of Malaysia. Companies Act 1965 (Act 125). The Government Press, Kuala Lumpur, 1965.

Government of Malaysia. Constitution (Amendment) (No.2) Act 1973. The Government Press, Kuala Lumpur, 1973.

Government of Malaysia. Petroleum Development Act, 1974 (Act 144). The Government Press, Kuala Lumpur, 1974.

Government of Malaysia. Petroleum Mining Act 1966.The Government Press, Kuala Lumpur, 1966.

Government of Malaysia. National Petroleum Advisory Council. Petroluem Legislation, Bahagian Kemajuan Petroleum, Jabatan Perdana Menteri, File 276/PT.I, Arkib Negara Malaysia, 1975.

Government of Malaysia. National Petroleum Advisory Council. National Policy on Petroleum Industries, Kertas Kerja Bil. 1/75, Bahagian Kemajuan Petroleum, Jabatan Perdana Menteri, File 276/PT.I, Arkib Negara Malaysia, 1975.

Government of Malaysia. National Petroleum Advisory Council. Minute of Special Meeting on Petroleum Legislation, Bahagian Kemajuan Petroleum, Jabatan Perdana Menteri, File 276/PT.I, Arkib Negara Malaysia, 1974.

Government of Malaysia. National Petroleum Advisory Council. Minute of $4^{\text {th }}$ Meeting of National Petroleum Advisory Council, Bahagian Kemajuan Petroleum, Jabatan Perdana Menteri, File 276/PT.I, Arkib Negara Malaysia, 1975.

Government of Malaysia. National Petroleum Advisory Council. Minute of $6^{\text {th }}$ Meeting of National Petroleum Advisory Council, Bahagian Kemajuan Petroleum, Jabatan Perdana Menteri, File 276/PT.I, Arkib Negara Malaysia, 1975.

Government of Malaysia. Second Malaysia Plan 1971-1975, the Government Press, Kuala Lumpur:1972.

Government of Malaysia. Fifth Malaysia Plan 1986-1990, Economic Planning Unit, Prime Minister's Department Malaysia, Government Press, Kuala Lumpur: 1986.

Government of Malaysia. Penyata Rasmi Parlimen (Parliamentary Debates), Dewan Rakyat, Parlimen Keenam, Jilid III, Bil. 22, 24 Julai 1985.

Government of Malaysia. Penyata Rasmi Parlimen (Parliamentary Debates), Dewan Rakyat, Parlimen Keenam, Jilid III, Bil. 50, 21 November 1985.

Government of Malaysia. Penyata Rasmi Parlimen (Parliamentary Debates), Dewan Rakyat, Parlimen Ketujuh, Jilid II, Bil. 43, 4 November 1988. 
Government of Malaysia. Penyata Rasmi Parlimen (Parliamentary Debates), Dewan Rakyat, Parlimen Ketujuh, Jilid III, Bil. 1, 7 Mac 1989.

Government of Malaysia. Penyata Rasmi Parlimen (Parliamentary Debates), Dewan Rakyat, Parlimen Ketujuh, Jilid III, Bil. 6, 14 Mac 1989.

Government of Malaysia. Penyata Rasmi Parlimen (Parliamentary Debates), Dewan Rakyat, Parlimen Ketujuh, Jilid III, Bil. 16, 20 Jun 1989.

Government of Malaysia. Penyata Rasmi Parlimen (Parliamentary Debates), Dewan Rakyat, Parlimen Ketujuh, Jilid III, Bil. 22, 28 Jun 1989.

Government of Malaysia. Penyata Rasmi Parlimen (Parliamentary Debates), Dewan Negara, Parlimen Ketujuh, Jilid II, Bil. 10, 12 Julai 1988.

Government of Malaysia. Penyata Rasmi Parlimen (Parliamentary Debates), Dewan Rakyat, Parlimen Ketujuh, Jilid IV, Bil. 1, 27 Feb 1990.

Government of Malaysia. Penyata Rasmi Parlimen (Parliamentary Debates), Dewan Rakyat, Parlimen Ketujuh, Jilid IV, Bil. 13, 15 Mac 1990.

Government of Malaysia. Penyata Rasmi Parlimen (Parliamentary Debates), Dewan Rakyat, Parlimen Ketujuh, Jilid IV, Bil. 24, 22 Jun 1990.

"Oil Companies in Malaysia: An Uncertain Feeling", The Financial Times, 3 June 1975.

PETRONAS, Sedekat Pembangunan PETRONAS, PETRONAS, Kuala Lumpur: 1985.

PETRONAS, Petronas dan Industri Petroleum Malaysia, Jabatan Hal Ehwal Awam, PETRONAS, Kuala Lumpur, 1984.

\section{Secondary Sources}

\section{Books:}

Bowie, Paddy, A Vision Realised: The Transformation of a National Oil Corporation, Orillia Corporation Sdn Bhd, Kuala Lumpur: 2001.

Gomez, Edmund Terence, Politics in Business UMNO's Corporate Investment, Forum, Kuala Lumpur: 1990.

Gomez, Edmund Terence, Money Politics in the Barisan Nasional, FORUM, Kuala Lumpur: 1990.

Gomez, Edmund Terence and Jomo K. S., Malaysia's Political Economy: Politics, Patronage and Profits, $2^{\text {nd }}$ edition, Cambridge University Press, London: 1999. 
Henderson, William O., Friedrich List: Economist and Visionary, London, Franck Cass, 1983.

Idris, Zulkifli, Privatization in Malaysia: A Case Study of the Impact of Privatization on Privatized Public Agencies, University of Southern California, California: 1995.

Jesudason, James V., Ethnicity and the Economy: The State, Chinese Business, and Multinationals in Malaysia, Oxford University Press, Singapore: 1990.

Jomo K. S., Privatizing Malaysia: Rents, Rhetoric, Realities, Westview Press Oxford: 1995.

Jomo K. S. and Tan Wooi Syn, Privatization And Renationalization In Malaysia: A Survey, Kuala Lumpur: 1995.

Searle, Peter, The Riddle of Malaysian Capitalism, Rent-Seekers or Real Capitalist? Allen \& Uwin and University of Hawaii Press, Honolulu: 1999.

\section{Journal Article:}

Borrows, Gordon, "The Production-Sharing Contract of Malaysia, the Philippines, and Egypt", The Petroleum Potential of Non-OPEC Countries, Graham \& Trotman, London: 1988.

Gomez, Edmund Terence, "Political Business: Corporate Involvement of Malaysian Political Parties", Centre for South-East Asian Studies, James Cook University of North Queensland, Townsville: Australia 1994.

Gomez, Edmund Terence, "Enterprise Development and Inter-Ethnic Relations in Malaysia: Affirmative Action, Generational Change, and Business Partnerships", Centre for Policy Initiatives, 2005.

Gomez, Edmund Terence, "Malaysian Business Group: The State and Capital Development in the Post-Currency Crisis Period", Centre for Policy Initiatives, 2005.

Gomez, Edmund Terence, "Corporate Equity Distribution: Past Trends and Future Policy”, Centre for Public Policy Study, Kuala Lumpur: 2005.

Ho, Khai Leong, "Indigenizing The State: The New Economic Policy and The Bumiputera State in Peninsular Malaysia" Doctoral Thesis, University Microfilms International, The Ohio State University: 1988.

Mohamed, Rugayah, "Public Enterprises", Privatizing Malaysia: Rents, Rhetoric, Realities, ed. Jomo K.S., Westview Press, Oxford: 1995. 